\title{
Characterization of Human Coronaviruses on Well-Differentiated Human Airway Epithelial Cell Cultures
}

\author{
Hulda R. Jonsdottir and Ronald Dijkman
}

\begin{abstract}
The human airway serves as the entry point of human respiratory viruses, including human coronaviruses. In this chapter we outline the methods by which we establish fully differentiated airway epithelium and its use for human coronavirus propagation. Additionally, we outline methods for immunofluorescence staining of these cultures for virus detection, characterization of cell tropism, and how to perform antiviral assays and quantify viral replication.
\end{abstract}

Key words Human coronavirus, Antivirals, Cell tropism, Human airway epithelial cells, Virus detection

\section{Introduction}

The human airway serves as the entry point of human respiratory viruses, including human coronaviruses (HCoVs). In order to properly recapitulate the complex anatomy of the human lung specialized cell culture models have been developed to resemble both the upper and lower airways [1-3]. Primary human bronchial epithelial cells cultured in an air-liquid interface (ALI) system serve as a universal platform to study human respiratory viruses [4-6]. These human airway epithelial (HAE) cultures morphologically and functionally resemble the upper conducting airways in vivo. In these cultures, the epithelial layer is pseudostratified and after differentiation they contain many different cell types such as basal, ciliated, and goblet cells and furthermore, generate protective mucus equivalent to that of in vivo epithelium [7].

Establishment of HAE cultures requires time and patience but the differentiated cultures allow for a number of advantageous analyses in respiratory virus research. We have adapted and optimized our methods based on previously published work [8-10]. Moreover, we have standardized methods for the propagation of human coronaviruses and evaluation of the effects of antiviral 
compounds on both viral replication and cell viability. We are able to propagate all known human coronaviruses in this system and can easily evaluate their tropism by immunohistochemistry $[5,11]$. In this chapter we outline the methods by which we establish fully differentiated airway epithelium and use it for human coronavirus propagation. Additionally, we outline methods for immunofluorescence staining of these cultures for virus detection, characterization of cell tropism and how to perform antiviral assays and quantify viral replication.

\section{Materials}

\subsection{Human Airway Epithelial Cell Cultures}

1. Primary human tracheobronchial epithelial cells can be obtained in accordance with local ethical guidelines from patients willing to give informed consent, who are undergoing bronchoscopy and/or surgical lung resections. Alternatively isolated primary human airway epithelial cells can be obtained commercially from a number of distributors.

2. 10× digestion solution: Minimum Essential Medium (MEM), $\mathrm{l} \% \mathrm{~m} / \mathrm{v}$ Protease from Streptomyces griseus Type XIV, $0.01 \% \mathrm{~m} / \mathrm{v}$ Deoxyribonuclease I from bovine pancreas.

3. Isolation/washing solution: MEM, $100 \mathrm{U} / \mathrm{ml}$ penicillin, $100 \mu \mathrm{g} / \mathrm{ml}$ streptomycin, $0.25 \mu \mathrm{g} / \mathrm{ml}$ Amphotericin B Solution, $50 \mu \mathrm{g} / \mathrm{ml}$ gentamicin, $100 \mathrm{U} / \mathrm{ml}$ nystatin.

4. Bronchial epithelial cell serum-free growth medium (BEGM): LHC basal medium, supplemented with the required additives (Table 1).

5. Air-liquid interface (ALI) medium: LHC basal medium and Dulbecco's Modified MEM (DMEM) mixed in a 1:1 ratio, supplemented with the required additives (Table 1 ).

6. 12-Well inserts, pore size $0.4 \mu \mathrm{M}$ and 12 -well cluster plates or 12-well deep well cluster plates.

7. 24-Well inserts pore size $0.4 \mu \mathrm{M}$ and 24 -well cluster plates.

8. Human collagen Type I + III, Vitrocol 100.

9. Collagen Type IV from human placenta reconstituted in $5 \mathrm{ml}$ filter-sterilized water with $0.25 \%$ acetic acid. Dissolve for a few hours at $37^{\circ} \mathrm{C}$, occasionally swirling. Once dissolved, increase volume to $20 \mathrm{ml}$ and maintain acetic acid concentration at $0.25 \%$, mix gently by pipetting. Filter-sterilize the solution through a $0.22 \mu \mathrm{m}$ filter, and store at $-20{ }^{\circ} \mathrm{C}$ in aliquots of $800 \mu \mathrm{l}$ per eppendorf tube. The stock solution is stable for at least 1 year at $-20^{\circ} \mathrm{C}$. 
Table 1

Preparation of stock additives for BEGM and ALI medium

\begin{tabular}{|c|c|c|}
\hline Component & Stock concentration & Comment \\
\hline Bovine Serum Albumin (BSA) & $300 \times 150 \mathrm{mg} / \mathrm{ml}$ & See Note 1 \\
\hline Bovine pituitary extract (BPE) & $1,000 \times \pm 14 \mathrm{mg} / \mathrm{ml}$ & \\
\hline Insulin & $2,000 \times, 10 \mathrm{mg} / \mathrm{ml}$ & Store at $+4^{\circ} \mathrm{C}$ \\
\hline Transferrin (TF) & $1,000 \times, 10 \mathrm{mg} / \mathrm{ml}$ & \\
\hline Hydrocortisone $(\mathrm{H})$ & $1,000 \times, 0.072 \mathrm{mg} / \mathrm{ml}$ & \\
\hline Triiodothyronine (T3) & $1,000 \times, 0,067 \mathrm{mg} / \mathrm{ml}$ & \\
\hline Epinephrine (EP) & $1,000 \times, 0.6 \mathrm{mg} / \mathrm{ml}$ & \\
\hline $\begin{array}{l}\text { Epidermal Growth Factor } \\
\text { (EGF) }\end{array}$ & $1,000 \times$ or $50,000 \times, 25 \mu \mathrm{g} / \mathrm{ml}$ & $\begin{array}{l}1,000 \times \text { for BEGM, } \\
50,000 \times \text { for ALI medium. }\end{array}$ \\
\hline Retinoic acid (RA) & $1,000 \times, 5 \times 10^{-5} \mathrm{M}$ & Light sensitive. See Note 2 \\
\hline Phosphorylethanolamine (PE) & $1,000 \times, 70 \mathrm{mg} / \mathrm{ml}$ & \\
\hline Ethanolamine (EA) & $1,000 \times, 30 \mu \mathrm{l} / \mathrm{ml}$ & \\
\hline Stock 11 (S11) & $1,000 \times, 0,863 \mathrm{mg} / \mathrm{ml}$ & \\
\hline Stock $4(S 4)$ & $1,000 \times$ & See Note 3 \\
\hline Trace Elements (TR) & $1,000 \times$ & See Note 4 \\
\hline Penicillin/Streptomycin $(\mathrm{P} / \mathrm{S})$ & $\begin{array}{l}100 \times 10,000 \mathrm{U} / \mathrm{ml} \text { of penicillin } \\
\text { and } 10,000 \mu \mathrm{g} / \mathrm{ml} \text { of streptomycin }\end{array}$ & Store at $+4^{\circ} \mathrm{C}$ \\
\hline Gentamicin & $1,000 \times, 50 \mathrm{mg} / \mathrm{ml}$ & Store at $+4^{\circ} \mathrm{C}$. See Note 5 \\
\hline Amphotericin B & $1,000 \times, 50 \mathrm{mg} / \mathrm{ml}$ & See Note 5 \\
\hline
\end{tabular}

All additives should be aliquoted and stored at $-20^{\circ} \mathrm{C}$ unless stated otherwise

\subsection{Human \\ Coronavirus \\ Propagation}

1. Apical wash solution: Hank's Balanced Salt Solution (HBSS), without calcium and magnesium.

2. Virus transport medium (VTM): MEM, $25 \mathrm{mM}$ HEPESbuffered, $0.5 \%$ gelatin, $100 \mathrm{U} / \mathrm{ml}$ penicillin, $100 \mu \mathrm{g} / \mathrm{ml}$ streptomycin.

3. Aerosol barrier pipette tips and $1.5 \mathrm{ml}$ Eppendorf Safe-Lock Tubes $^{\mathrm{TM}}$.

1. Fixation solution: $4 \%$ formalin solution, neutral buffered (Formafix).

2. Confocal staining buffer $(\mathrm{CB}): 50 \mathrm{mM}$ ammonium chloride $\left(\mathrm{NH}_{4} \mathrm{Cl}\right), 0.1 \%$ saponin, and $2 \% \mathrm{IgG}$ and protease-free BSA dissolved in $500 \mathrm{ml}$ of phosphate buffered saline (PBS, 
Table 2

\section{Primary antibodies}

\begin{tabular}{lllll}
\hline Antibody & Target & Dilution & Host & Comment \\
\hline Anti- $\beta$-Tubulin IV & Cilia & $1: 400$ & Mouse, IgGl & Clone ONS.1A6 \\
\hline anti-ZO1 & Tight junctions & $1: 200-400$ & Goat & $\begin{array}{l}\text { Directed against } \\
\text { C-terminal domain }\end{array}$ \\
\hline anti-dsRNA & dsRNA & $1: 500-1,000$ & Mouse, IgG2a & Clone J2 \\
\hline Anti-CD13 & CD13/APN & $1: 200$ & Sheep & Receptor 229E \\
\hline Anti-CD26 & CD26/DPPIV & $1: 200$ & Goat & Receptor MERS \\
\hline Anti-ACE2 & ACE2 & $1: 200$ & Goat & $\begin{array}{l}\text { Receptor SARS } \\
\text { and NL63 }\end{array}$ \\
\hline $\begin{array}{l}\text { intravenous } \\
\text { immunoglobulin } \\
\text { (IVIG) }\end{array}$ & Viral proteins & $1: 1,000$ & Human & \\
\hline $\begin{array}{l}\text { Anti- } \beta \text {-Tubulin } \\
\text { Cilia }\end{array}$ & & $1: 400$ & Mouse, IgGl & $\begin{array}{l}\text { Clone Tub2.1, } \\
\text { Cy3 conjugate }\end{array}$ \\
\hline
\end{tabular}

$\mathrm{pH} 7.4)$. Filter-sterilize $(0.2 \mu \mathrm{m}$ filter $)$ solution and prepare aliquots of $40 \mathrm{ml}$ and store at $-20{ }^{\circ} \mathrm{C}$.

3. Primary antibodies: see Table 2.

4. Fluorescent DNA dyes: DAPI or Hoechst 33528.

5. Wash solution: Phosphate buffered saline, $\mathrm{pH} 7.4$, without calcium and magnesium.

6. Scalpel (No.10).

7. Rat-tooth forceps.

8. Fluorescence Mounting Medium.

9. Gyro-rocker.

2.4 Antiviral Assays

\subsection{Virus Detection}

\subsubsection{Renilla}

Luciferase Assay

2.5.2 Plaque Assay
1. Inhibitors: e.g. K22 [12], recombinant Interferon Alpha and Lambda proteins [13].

2. CellTiter-Glo ${ }^{\circledR}$ Luminescent Cell Viability Assay (Promega).

1. Renilla Luciferase Assay System (Promega).

2. White, non-transparent 96-well plates.

3. Gyro-rocker.

4. Luminometer.

1. Huh-7 cells.

2. Medium: DMEM, high glucose, $100 \mathrm{U} / \mathrm{ml}$ penicillin, $100 \mu \mathrm{g} / \mathrm{ml}$ streptomycin, $1 \mathrm{mM}$ Sodium Pyruvate, $5 \%$ heat-inactivated FBS. 
2.5.3 Quantitative Reverse Transcriptase PCR
3. Overlay medium: $2.4 \mathrm{~g}$ of Avicel RC-581 (FMC biopolymer) dissolved in $100 \mathrm{ml}$ of distilled water and autoclaved for $20 \mathrm{~min}$ at $121^{\circ} \mathrm{C} .2 .7 \mathrm{~g}$ of DMEM powder (high glucose) dissolved in $90 \mathrm{ml}$ of distilled water and the $\mathrm{pH}$ adjusted to 7.4 with $1 \mathrm{M}$ $\mathrm{NaOH}$. Fill volume up to $100 \mathrm{ml}$ and filter-sterilize $(0.2 \mu \mathrm{m}$ filter). Freshly prepare a $1: 1$ mixture of Avicel $(2.4 \%)$ and $2 \times$ DMEM solution, supplemented with $10 \%$ FBS and $100 \mathrm{U} / \mathrm{ml}$ penicillin, $100 \mu \mathrm{g} / \mathrm{ml}$ streptomycin.

4. Crystal-violet solution: $25 \mathrm{~g}$ of Crystal Violet, $40 \mathrm{~g} \mathrm{NaCl}$ dissolved in 2,500 $\mathrm{ml}$ of $99 \%$ Ethanol. Add 2,250 ml of distilled water and $250 \mathrm{ml}$ of $37 \%$ formaldehyde. Mix solution overnight at room temperature (see Note 6).

1. Nucleospin RNA isolation kit (Machery Nagel).

2. Moloney Murine Leukemia Virus Reverse Transcriptase (M-MLV RT).

3. Random primers.

4. RNAse-free water.

5. FastStart Universal SYBR Green Master reaction mixture (Roche).

6. Positive control; in vitro transcribed RNA of target gene or plasmid DNA containing target gene.

\section{Methods}

Carry out all procedures in a biosafety cabinet according to local biosafety regulations.

\subsection{Human Airway Epithelial Cell Cultures}

3.1.1 Collagen Type I and III Coating of Cell Culture Flasks

Cell culture flasks are coated for $2 \mathrm{~h}$ with a mixture of Type I and III collagen that is necessary to efficiently expand the number of primary airway epithelial cells.

1. Use filter-sterilized $\mathrm{dH}_{2} \mathrm{O}(0.22 \mu \mathrm{m})$ to prepare a $1: 75$ dilution of Vitrocol 100.
2. Use $4 \mathrm{ml}$ per $75 \mathrm{~cm}^{2}$, make sure the entire surface is covered with the collagen solution.

3. Incubate for $2 \mathrm{~h}$ at $37^{\circ} \mathrm{C}$.

4. Aspirate remaining liquid and wash twice with $10 \mathrm{ml}$ of PBS to remove traces of acetic acid.

5. Culture flasks can be directly used. Optional: Store coated flasks at $+4{ }^{\circ} \mathrm{C}$ for a maximum of 6 weeks. 
3.1.2 Collagen Type IV Coating of Inserts

3.1.3 Isolation of Primary Human Tracheal and/or Bronchial Cells
The inserts need to be coated overnight with collagen type IV, necessary for development and long-term maintenance of differentiated primary airway epithelial cell cultures.

1. Mix $7.2 \mathrm{ml}$ of filter-sterile $\mathrm{dH}_{2} \mathrm{O}$ with $800 \mu \mathrm{l}$ of Collagen Type IV solution $(0.5 \mathrm{mg} / \mathrm{ml})$.

2. Apply $150 \mu \mathrm{l}$ per 12 -well inserts, or $50 \mu \mathrm{l}$ per 24 -well inserts. After completing one plate, make sure that the entire surface of each well is covered with the 1:10 collagen solution.

3. Air-dry the inserts overnight in a laminar flowhood, and afterwards expose them to UV-light (type C) for $30 \mathrm{~min}$.

4. To remove traces of acetic acid wash inserts twice with at least $500 \mu \mathrm{l}$ of PBS.

5. After these steps, coated inserts can be used directly. Optional: Store at $+4{ }^{\circ} \mathrm{C}$ (wrapped in foil) for a maximum of 6 weeks. Repeat UV-exposure and washing steps before use.

Primary epithelial cells can be isolated from whole lung tissue resections of tracheal and/or bronchial origin according to the following protocol. Smaller lung tissue resections can be processed with the same protocol. All procedures are performed at room temperature unless stated otherwise.

1. Trim the bronchial tissue free of connective tissue and fat using forceps and scissors or a scalpel. If needed, cut the bronchial tissue into $2 \mathrm{~cm}$ segments.

2. Wash the cleaned tissue three times in washing solution.

3 . Fill the desired number of $50 \mathrm{ml}$ tubes with $30 \mathrm{ml}$ of wash solution and transfer as many tissue segments as possible into a single tube, until the volume reaches $36 \mathrm{ml}$. Then add $4 \mathrm{ml}$ of 10x digestion solution to each tube, to end volume $40 \mathrm{ml}$ (40 mg Protease/0.4 mg DNase).

4. Place tubes on a rocking platform/tube roller at $+4{ }^{\circ} \mathrm{C}$ and incubate for $48 \mathrm{~h}$.

5. Place the $50 \mathrm{ml}$ tube containing the digested tissue on ice and add $4 \mathrm{ml}$ of heat-inactivated FBS to each tube (to a final concentration of $10 \%(\mathrm{v} / \mathrm{v}))$, to neutralize protease activity. Invert tubes three times.

6. Pour solution along with the tissue onto a large petri dish, and gently scrape off the epithelium from the collagen-cartilage surface, using a scalpel in the reverted angle. Pool solutions containing dissociated cells into a $50 \mathrm{ml}$ conical tube and wash the petri dish once with PBS.

7. Centrifuge for $5 \mathrm{~min}$ at $500 \times g$. Wash cells once with HBSS and resuspend cells in BEGM to a concentration of, approximately, $5 \times 10^{6}$ cells $/ \mathrm{ml}$. 


\subsubsection{Establishment of Fully Differentiated HAE Cultures}

8. Count cells using a hemocytometer and seed into collagen coated flasks with $20 \mathrm{ml}$ of pre-warmed BEGM. An appropriate amount of cells for T75 flasks ranges between 0.5 and $1.0 \times 10^{6}$ cells.

9. Change medium the next day to remove red blood cells and any unattached epithelial cells.

10. To prevent acidification of the medium change it every $2-3$ days, until 80-90\% confluence.

When the primary cells have reached $80-90 \%$ confluence in the expansion phase one can dissociate and seed the dedifferentiated primary cells on collagen type IV coated inserts, according to the following protocol. All procedures are performed at room temperature unless stated otherwise.

1. Remove BEGM and transfer it into a $50 \mathrm{ml}$ tube and wash the cell monolayer twice with $12 \mathrm{ml}$ of HBSS.

2. Dissociate the bronchial cells for $3 \mathrm{~min}$ at $37^{\circ} \mathrm{C}$ in a humidified $5 \% \mathrm{CO}_{2}$ incubator with the appropriate amount of trypsin $\left(25 \mathrm{~cm}^{2}: 1 \mathrm{ml}, 75 \mathrm{~cm}^{2}: 3 \mathrm{ml}\right)$. If needed tap the flask to dissociate the cells (see Note 7 ).

3 . Collect the cells in the previously collected BEGM and centrifuge for $5 \mathrm{~min}$ at $500 \times \mathrm{g}$.

4. Carefully discard the supernatant and resuspend cells in HBSS and centrifuge the suspension for $5 \mathrm{~min}$ at $500 \times \mathrm{g}$.

5 . Discard the supernatant and resuspend cells in pre-warmed ALI medium and count using a hemocytometer.

6. For generation of differentiated HAE cultures the number of cells seeded should be $1.0-2.0 \times 10^{5}$ cells per 12 -well insert in $500 \mu \mathrm{l}$, or $0.3-0.6 \times 10^{5}$ cells per 24 -well insert in $200 \mu \mathrm{l}$ of ALI medium. A single $75 \mathrm{~cm}^{2}$ flask should provide enough cells for preparing 48 individual 12 -well inserts or 96 individual 24-well inserts.

7. Fill the basolateral compartment of the plates with $1 \mathrm{ml}$ of ALI medium ( $500 \mu \mathrm{l}$ for 24-well inserts), and transfer $500 \mu \mathrm{l}$ (200 $\mathrm{\mu l}$ for 24-well inserts) of diluted cell suspension to the upper chamber of the collagen coated inserts and incubate overnight at $37{ }^{\circ} \mathrm{C}$ in a humidified $5 \% \mathrm{CO}_{2}$ incubator. Cells are now in liquid-liquid interface.

8. The next day, medium in the apical compartment must be changed to remove any unattached cells. Discard the old medium and wash the apical surface with $500 \mu \mathrm{HBSS}$ and apply $500 \mu \mathrm{l}$ of pre-warmed ALI medium to the apical side. Adjust volume to $200 \mu \mathrm{l}$ for 24 -well inserts. 
9. To prevent acidification of the medium it should be changed every 2-3 days until cells have reached complete confluence (see Note 8).

10. During media change in liquid-liquid interface change apical medium first (as described in step 8) followed by exchange of medium in the basolateral compartment.

11. To establish air-liquid interface, aspirate apical side medium, once cells have reached complete confluence, and wash twice with HBSS $(500 \mu \mathrm{l}$ for 12 -well inserts and $200 \mu \mathrm{l}$ for 24 -well inserts).

12. Incubate cultures for a few hours at $37{ }^{\circ} \mathrm{C}$ in a humidified $5 \%$ $\mathrm{CO}_{2}$ incubator and monitor if seeping of basolateral medium into the apical compartment occurs. If no seepage occurs cultures can be maintained at air-liquid interface. Otherwise cultures have to be cultured at liquid-liquid interface for another day.

13. Incubate cultures for 4-6 weeks to allow differentiation. Appearance of active ciliated cells can be used as an indicator of differentiation. During the extended culture time medium must be changed regularly (every $2-3$ days). If desired, inserts can be transferred to deep well plates that only require medium renewal every 7 days.

14. After differentiation HAE cultures are suitable for human coronavirus propagation.

3.2 Human

Coronavirus

Propagation
1. Wash the apical surface of the HAE culture twice with $500 \mu \mathrm{l}$ of HBSS solution prior to inoculation with human coronavirus specimen to remove excess of mucus.

2. Dilute the clinical material or virus supernatant in HBSS and inoculate $200 \mu \mathrm{l}$ dropwise to the apical surface and incubate for $2 \mathrm{~h}$ at either $33{ }^{\circ} \mathrm{C}$ or $37^{\circ} \mathrm{C}$ ( see Note 9), in a humidified $5 \% \mathrm{CO}_{2}$-incubator. Optional: Centrifuge inoculum solution for $4 \mathrm{~min}$ at $1,500 \times \mathfrak{g}$ at room temperature to remove cell debris prior to inoculation.

3 . Collect the inoculum and transfer it to a container and store at $-80{ }^{\circ} \mathrm{C}$ for later analysis, and wash the apical surface three times with $500 \mu \mathrm{l} \mathrm{HBSS}$. Optional: Transfer the collected inoculum into an equal volume of VTM.

4. Incubate the infected cultures for the desired amount of time at the appropriate temperature in a humidified $5 \% \mathrm{CO}_{2^{-}}$ incubator, e.g. $48 \mathrm{~h}$ at $33{ }^{\circ} \mathrm{C}$ for $\mathrm{HCoV}-229 \mathrm{E}$.

5. Apply $200 \mu \mathrm{l}$ of HBSS dropwise to the apical surface $10 \mathrm{~min}$ prior to the desired collection time and incubate in the humidified $5 \% \mathrm{CO}_{2}$-incubator. Then collect progeny virus and transfer it to a container and store at $-80{ }^{\circ} \mathrm{C}$ for later analysis. Optional: Transfer the collected progeny virus into an equal volume of VTM. 


\subsection{Immuno- fluorescence Analysis}

All incubation steps are performed at room temperature on a gyrorocker (20-30 rpm), unless stated otherwise

1. After the apical washing has been collected the apical surface is washed twice with $500 \mu \mathrm{l}$ of PBS before cells are fixed with formalin-solution for later immunofluorescence analysis.

2. Apply $500 \mu \mathrm{l}$ of $4 \%$ formalin-solution to the apical compartment and $1 \mathrm{ml}$ to the basolateral. Incubate for $15-30 \mathrm{~min}$.

3. Remove the formalin-solution and wash both compartments three times with equal volumes of PBS.

4. Transfer the fixed HAE cultures to a new conventional 12-well plate.

5. Discard washing solution and apply $500 \mu \mathrm{l}$ and $1 \mathrm{ml}$ of confocal buffer (CB) solution to apical and basolateral compartments, respectively.

6. Incubate fixed cultures for 30-60 min to block non-specific binding of antibodies ( see Note 10).

7. Remove the $\mathrm{CB}$ solution from the apical and basolateral compartments.

8. From this stage one should only apply $\mathrm{CB}$ solution to the apical compartment.

9. Wash the apical surface once with $500 \mu \mathrm{l}$ of $\mathrm{CB}$ solution for $5 \mathrm{~min}$.

10. Apply primary antibodies (see Table 2) diluted in $250 \mu \mathrm{CB}$ solution dropwise to the apical surface and incubate for $120 \mathrm{~min}$.

11. Wash the apical surface three times with $500 \mu \mathrm{l}$ of CB solution for 5 min (see Note 11).

12. Apply the appropriately diluted conjugated secondary antibodies in $250 \mu \mathrm{l} \mathrm{CB}$ solution dropwise to the apical surface and incubate for $60 \mathrm{~min}$.

13. Wash the apical surface twice with $500 \mu \mathrm{l}$ of CB solution for $5 \mathrm{~min}$.

14. Incubate cells with nucleic acid counter stain solution diluted in $250 \mu \mathrm{l}$ of CB solution for $5 \mathrm{~min}$.

15. Wash the apical surface once with $500 \mu \mathrm{l}$ of CB solution for $5 \mathrm{~min}$.

16. Lastly, wash the apical surface twice with $500 \mu \mathrm{l}$ of PBS for $5 \mathrm{~min}$ to remove residual saponin and restore cell membrane integrity.

17. Before removing the washing solution, apply mounting medium on a glass slide (use 1-2 drops). Remove any air bubbles. 


\subsection{Antiviral Assays}

\subsubsection{Treatment}

18. Excise the membrane from the plastic holder and carefully place the basolateral side of the membrane on top of the mounting medium, without generating air bubbles.

19. Then slowly add one drop of mounting medium on top of each membrane.

20. Slowly place the coverslip, in a tilted fashion, on top of the membrane without generating air bubbles.

21. Allow the mounting medium to polymerize for $30 \mathrm{~min}$, after which the slide can directly be analyzed.

1. Pre-warm ALI medium to $37^{\circ} \mathrm{C}$.

2. Mix antiviral compounds (e.g. K22, recombinant interferons) in various concentrations or by serial dilution in ALI medium. Include non-treated controls. Also, to exclude viral inhibition by solvents (e.g. DMSO) include solvent controls.

3. For evaluation of either prophylactic or therapeutic effects of antivirals, the HAE cultures can be incubated with the compounds diluted in the basolateral medium prior to, during or after infection.

4. Infect cultures apically with human coronaviruses as described in Subheading 3.2.

5. Collect apical washings in HBSS as described in Subheading 3.2 for viral quantification by plaque assay and cells for viral quantification by Renilla Luciferase Assay or qRT-PCR.

1. Thaw CellTiter-Glo buffer and equilibrate both buffer and CellTiter-Glo substrate to room temperature.

2. Transfer the buffer to the amber bottle containing the substrate to reconstitute the enzyme. Mix by gently swirling the bottle.

3. Wash the apical side of the HAE cultures three times with $500 \mu \mathrm{HBSS}$ to remove excess mucus.

4. Apply $50 \mu \mathrm{l}$ of HBSS to the apical side and mix with equal volume of reconstituted CellTiter-Glo enzyme solution (optimized for 24-well inserts, for other insert sizes adjust buffer amount accordingly) and incubate for $5 \mathrm{~min}$ at room temperature on a gyro-rocker to induce cell lysis.

5. Next incubate the plate for $10 \mathrm{~min}$ at room temperature to allow for stabilization of the luminescence signal.

6. Transfer $20 \mu \mathrm{l}$ of cell lysate to a white, non-transparent 96-well plate for analysis.

7. Record luminescence (see Note 12). To account for background signal include empty wells in your analysis. 


\subsection{Virus Detection}

3.5.1 Renilla Luciferase Assay (See Note 13)

3.5.2 Plaque Assay

1. Thaw Renilla Luciferase Assay buffer and dilute 1:5 in water.

2. Wash HAE inserts with HBSS three times prior to cell lysis.

3 . Incubate inserts with $80 \mu \mathrm{l}$ of Renilla lysis buffer on a gyrorocker for $30 \mathrm{~min}$ at room temperature (optimized for 24-well inserts, adjust lysis buffer amount accordingly for other insert sizes).

4. During incubation, thaw Renilla Assay buffer.

5. Transfer the cell lysate to a 96-well plate.

6. Transfer $20 \mu \mathrm{l}$ of the lysate to a white, non-transparent 96-well plate for analysis.

7. Add Renilla substrate at 1:200 dilution to the required amount of Renilla Assay buffer (100 $\mu$ l per sample). Protect from light (see Note 14).

8. Program your luminometer settings with $10 \mathrm{~s}$ measure time followed by a 2 s delay. $100 \mu \mathrm{l}$ of assay buffer should be dispensed into each well. If the luminometer is not equipped with an injector the assay buffer can be added manually using a multichannel pipette.

9. To adjust samples for background include empty wells in your analysis.

10. Plot your values as $\log _{10}$ RLU (Relative Light Units).

The current protocol is optimized for $\mathrm{HCoV}-229 \mathrm{E}$, but can easily be adapted to any other cell line and coronavirus strain.

1. Seed 150,000 target cells in a 12 -well cluster plates with $1 \mathrm{ml}$ of complete medium per well and incubate overnight at $37{ }^{\circ} \mathrm{C}$ in a humidified $5 \% \mathrm{CO}_{2}$-incubator.

2. Make 6 tenfold serial dilutions of the harvested virus supernatants in $1 \mathrm{ml}$ and inoculate the cells.

3. Incubate inoculum for $2 \mathrm{~h}$ at $33{ }^{\circ} \mathrm{C}$ in a humidified $5 \% \mathrm{CO}_{2^{-}}$ incubator before removing the serial diluted virus inoculums from the cells and replace with $1 \mathrm{ml}$ of overlay medium.

4. Incubate titration plates for $3-4$ days at $33{ }^{\circ} \mathrm{C}$ in a humidified $5 \% \mathrm{CO}_{2}$-incubator.

5. Remove overlay and wash wells twice with water to remove residual Avicel.

6. Subsequently add approximately $0.5-1 \mathrm{ml}$ of crystal violet solution to each well and incubate for $10 \mathrm{~min}$.

7. Remove crystal violet solution and wash the cells once with water and allow the plates to air-dry before counting the number of plaques. 
3.5.3 Quantitative

Reverse Transcriptase PCR
1. Isolate viral RNA with NucleoSpin RNA kit according to the manufacturer's protocol and elute in the appropriate amount of RNase-free water.

2. For reverse transcription use M-MLV reverse transcriptase (100 U), M-MLV buffer, and random primers and $10 \mu \mathrm{l}$ of extracted total RNA in a total volume of $20 \mu \mathrm{l}$, at $37^{\circ} \mathrm{C}$ for $60 \mathrm{~min}$. Optional: include serial dilutions of in vitro transcribed RNA of the target gene for virus yield quantification.

3. To quantify viral $\mathrm{HCoV}$ RNA yields from contemporary strains use the FastStart Universal SYBR Green Master reaction mixture. Amplify $2 \mu \mathrm{l}$ of cDNA according to the manufacturer's protocol, using the previously published sense and antisense strain-specific primers ( see Note 15). Measurements and analysis can, for instance, be done on a LightCycler 480 II instrument, using the LightCycler 480 software package (Roche). Use the following cycle profile of $10 \mathrm{~min}$ at $95^{\circ} \mathrm{C}$ followed by 45 cycles of $10 \mathrm{~s}$ at $95^{\circ} \mathrm{C}, 20 \mathrm{~s}$ at $60^{\circ} \mathrm{C}$, and $30 \mathrm{~s}$ at $72^{\circ} \mathrm{C}$ followed by a melting curve step to confirm product specificity.

\section{Notes}

1. Dissolve $5 \mathrm{~g}$ of BSA, globulin free, powder in $20 \mathrm{ml}$ PBS in a $50 \mathrm{ml}$ tube (do not vortex). Place the tube on a shaker/rollerbank for $2-4(\max 24)$ hours at $+4{ }^{\circ} \mathrm{C}$, until the BSA is completely dissolved. Add the volume up to $34 \mathrm{ml}$, mix gently by inverting the tube three times. Filter-sterilize the solution through a $0.22 \mu \mathrm{m}$ filter, and store at $-20{ }^{\circ} \mathrm{C}$ in aliquots of $3.5 \mathrm{ml}$ in $15 \mathrm{ml}$ tubes. Invert the tube three times before usage.

2. Dissolve $12 \mathrm{mg}$ of Retinoic Acid (RA) in $40 \mathrm{ml}$ absolute EtOH in a $50 \mathrm{ml}$ tube wrapped in aluminum foil, the RA-EtOH stock $\left(1 \times 10^{-3} \mathrm{M}\right)$ should be stored at $-20^{\circ} \mathrm{C}$. To prepare the $1,000 \times$ stock, first confirm the RA concentration of the ethanol stock by diluting it $1: 100$ in absolute EtOH. Measure the absorbance at $350 \mathrm{~nm}$ using a spectrophotometer and a $1 \mathrm{~cm}$ light path quartz cuvette (or NanoDrop with $0.1 \mathrm{~cm}$ light path), blanked on $100 \% \mathrm{EtOH}$. The absorbance of the diluted stock should equal 0.45 ( 0.045 on a NanoDrop). RA absorbance readings below 0.18 should be discarded. If the absorbance equals 0.45 , add $3 \mathrm{ml}$ of RA-EtOH stock solution to $53 \mathrm{ml} \mathrm{PBS}$ and add $4 \mathrm{ml}$ of BSA $150 \mathrm{mg} / \mathrm{ml}$ stock. For absorbance values less than 0.45 , calculate the needed volume of $\mathrm{RA}-\mathrm{EtOH}$ stock as 1.35/absorbance and adjust the PBS volume appropriately. The $1,000 \times$ stock solution should be stored at $-20{ }^{\circ} \mathrm{C}$ in aliquots of $1 \mathrm{ml}$ per eppendorf tube.

3. Dissolve $42 \mathrm{mg}$ ferrous sulfate, $12.2 \mathrm{~g}$ magnesium chloride, and $1.62 \mathrm{~g}$ calcium chloride-dihydrate in $80 \mathrm{ml} \mathrm{H}_{2} \mathrm{O}$, add 
$500 \mu \mathrm{l}$ concentrated hydrochloric acid $(\mathrm{HCl})$. Filter-sterilize the solution through a $0.22 \mu \mathrm{m}$ filter, and store at $-20{ }^{\circ} \mathrm{C}$ in aliquots of $1,100 \mu \mathrm{l}$ per eppendorf tube.

4. Prepare seven separate 25 or $50 \mathrm{ml}$ stock solutions (see Table 3a and $\mathrm{b}$ ) in $\mathrm{H}_{2} \mathrm{O}$. Filter-sterilize $(0.22 \mu \mathrm{m})$ each component after preparation. Afterwards, transfer an aliquot of $50 \mu \mathrm{l}$ from each separate component into $49,600 \mu \mathrm{l}$ filter-sterilized water $(0.22 \mu \mathrm{m})$ and add a volume of $50 \mu \mathrm{l}$ concentrated $\mathrm{HCl}$ solution. Mix the solution well through gentle vortexing and filtersterilize the solution through a $0.22 \mu \mathrm{m}$ filter, and store at $-20^{\circ} \mathrm{C}$ in aliquots of $1,100 \mu \mathrm{l}$ per eppendorf tube.

5. Gentamicin and Amphotericin B should be omitted from ALI medium. These antibiotics are only required in BEGM medium right after cell isolation to prevent contamination.

6. For preparation of crystal violet solution safety glasses and protective clothing should be worn. Any spillage must be cleaned with $96 \%$ ethanol.

7. Cells might take longer to dissociate from the bottom of the flask due to the collagen coating. If the cells are not dissociated after 3 min additional rounds of 1 -min incubations can be performed until all cells have detached.

8. The seeded primary cells should reach confluence on the inserts within I week. If this takes longer the success rate of establishing well differentiated HAE cultures declines exponentially.

\section{Table 3}

Stock solutions for trace elements

(a)

\begin{tabular}{llll}
\hline Component & Formula & Amount/25 ml & Comment \\
\hline Selenium & $\mathrm{NaSeO}_{3}$ & $130.0 \mathrm{mg}$ & Solution stable for 30 days at $+4{ }^{\circ} \mathrm{C}$ \\
Silicone & $\mathrm{Na}_{2} \mathrm{SiO}_{3} \cdot 9 \mathrm{H}_{2} \mathrm{O}$ & $3.55 \mathrm{~g}$ & \\
Molybdenum & $\left(\mathrm{NH}_{4}\right)_{6} \mathrm{Mo}_{7} \mathrm{O}_{24} \cdot 4 \mathrm{H}_{2} \mathrm{O}$ & $31.0 \mathrm{mg}$ & \\
Vanadium & $\mathrm{NH}_{4} \mathrm{VO}_{3}$ & $14.75 \mathrm{mg}$ & Heat $>100{ }^{\circ} \mathrm{C}$ to dissolve \\
\hline
\end{tabular}

(b)

\begin{tabular}{llll}
\hline Component & Formula & Amount/50 ml & Comment \\
\hline Nickel & $\mathrm{NiSO}_{4} \cdot 6 \mathrm{H}_{2} \mathrm{O}$ & $13.0 \mathrm{mg}$ \\
Tin & $\mathrm{SnCl}_{2} \cdot 2 \mathrm{H}_{2} \mathrm{O}$ & $5.5 \mathrm{mg}$ \\
Manganese & $\mathrm{MnCl}_{2} \cdot 4 \mathrm{H}_{2} \mathrm{O}$ & $10.0 \mathrm{mg}$ \\
\hline
\end{tabular}


9. Human coronavirus NL63, 229E, HKU1, and OC43 are predominantly found in the upper respiratory tract and are therefore incubated at $33^{\circ} \mathrm{C}$. Both MERS-CoV and SARS-CoV are predominantly found in the lower respiratory tract and are therefore incubated at $37^{\circ} \mathrm{C}$.

10. The fixed HAE cultures can be kept for $1-3$ months at $4{ }^{\circ} \mathrm{C}$ if the $\mathrm{CB}$ is filter-sterilized $(0.2 \mu \mathrm{M})$ and all the procedure were performed under sterile conditions. After cold storage it is preferential to acclimatize the fixed cultures for $15 \mathrm{~min}$ to room temperature on a gyro-rocker (20-30 rpm) prior to continuation of the staining protocol.

11. To prevent bleaching of the fluorophores one should cover the inserts from daylight exposure during each incubation step.

12. Luminometer settings depend on the manufacturer. However, a measurement time of 1-2 s per well has proved effective.

13. For this assay cultures must be infected with coronaviruses expressing a Renilla Luciferase reporter gene.

14. If your luminometer is equipped with an injector you must remember to account for priming by increasing the volume of required Renilla Assay buffer by $2-3 \mathrm{ml}$.

15. Primers targeting HCoV-NL63, HCoV-HKUl, HCoV-229E, and $\mathrm{HCoV}-\mathrm{OC} 43$ have been characterized and described [4, 14, 15].

\section{Acknowledgement}

This work was supported by the 3R Research Foundation Switzerland (project 128-11).

\section{References}

1. de Jong PM, van Sterkenburg MA, Hesseling SC et al (1994) Ciliogenesis in human bronchial epithelial cells cultured at the air-liquid interface. Am J Respir Cell Mol Biol $10(3): 271-277$

2. Lin $\mathrm{H}, \mathrm{Li} \mathrm{H}$, Cho HJ et al (2007) Air-liquid interface (ALI) culture of human bronchial epithelial cell monolayers as an in vitro model for airway drug transport studies. J Pharm Sci 96(2):341-350

3. Fuchs S, Hollins AJ, Laue $M$ et al (2003) Differentiation of human alveolar epithelial cells in primary culture: morphological characterization and synthesis of caveolin- 1 and surfactant protein-C. Cell Tissue Res 311(1):31-45
4. Pyrc K, Sims AC, Dijkman R et al (2010) Culturing the unculturable: human coronavirus HKUl infects, replicates, and produces progeny virions in human ciliated airway epithelial cell cultures. J Virol 84(21):11255-11263

5. Kindler E, Jonsdottir HR, Muth D et al (2013) Efficient replication of the novel human betacoronavirus EMC on primary human epithelium highlights its zoonotic potential. MBio 4(1):e0611-e00612

6. Thompson CI, Barclay WS, Zambon MC et al (2006) Infection of human airway epithelium by human and avian strains of influenza a virus. J Virol 80(16):8060-8068 
7. Bernacki SH, Nelson AL, Abdullah L et al (1999) Mucin gene expression during differentiation of human airway epithelia in vitro. Muc4 and muc5b are strongly induced. Am J Respir Cell Mol Biol 20(4):595-604

8. Gray TE, Guzman K, Davis CW et al (1996) Mucociliary differentiation of serially passaged normal human tracheobronchial epithelial cells. Am J Respir Cell Mol Biol 14(1):104-112

9. Lechner J, LaVeck M (1985) A serum-free method for culturing normal human bronchial epithelial cells at clonal density. J Tissue Cult Methods 9(2):43-48

10. Fulcher ML, Gabriel S, Burns KA et al (2005) Well-differentiated human airway epithelial cell cultures. Methods Mol Med 107:183-206

11. Dijkman R, Jebbink MF, Koekkoek SM et al (2013) Isolation and characterization of current human coronavirus strains in primary human epithelial cell cultures reveal differences in target cell tropism. J Virol 87(11):6081-6090
12. Lundin A, Dijkman $R$, Bergstrom $T$ et al (2014) Targeting membrane-bound viral RNA synthesis reveals potent inhibition of diverse coronaviruses including the middle East respiratory syndrome virus. PLoS Pathog 10(5):e1004166

13. Hamming OJ, Terczynska-Dyla E, Vieyres G et al (2013) Interferon lambda 4 signals via the IFNlambda receptor to regulate antiviral activity against $\mathrm{HCV}$ and coronaviruses. EMBO J 32(23):3055-3065

14. Schildgen $\mathrm{O}$, Jebbink MF, de Vries $M$ et al (2006) Identification of cell lines permissive for human coronavirus NL63. J Virol Methods $138(1-2): 207-210$

15. Vijgen L, Keyaerts E, Moes E et al (2005) Development of one-step, real-time, quantitative reverse transcriptase PCR assays for absolute quantitation of human coronaviruses OC43 and 229E. J Clin Microbiol $43(11): 5452-5456$ 